\title{
Importance Autopsy for Investigation of a Case
}

\author{
Besim Arifi \\ MSc, PhD Cand. European University of Tirana
}

\begin{abstract}
Among the very important investigative actions is the autopsy. It is conducted by forensic doctors that workcompetent. The autopsy realized with a court order and performed the function of whitening/lightening of the investigation, given that the main purpose is to conduct the autopsy the cause of death. The assignment of cause of death, carried out with scientific methods by doctors who are open corpse are able to describe all wounds and other injuries caused by any means or substance that is used in connection with the case which has caused death person. Such a finding is of particular importance, because it orients the court and the prosecution in the right direction and also helps in determining the overall investigation. The autopsy realized that almost all cases of suspected violent death of any nature whatsoever. Also it developed to see the inside of the human body, through which remain wound caused by guns or by other means, as well as those who have followed the path during the passage through the human body. During the autopsy done and external examination of the corpse underskirt any stage or time that the body was found. Even if the corpse found after a certain time is still required an examination of detail of that corpse, to examine and ascertain the condition in which it found it first and wounds that had and description of all positions these wounds. We can say that a criminal investigation is halved in terms of its validity, if in this case the information is not developed autopsy. Professional court would not accept any test given on the case, if the same does not report detailed the autopsy.
\end{abstract}

Keywords: autopsy, court, examination, corpse, injury

\section{Introduction}

An autopsy is the best evidence possible to establish the cause of death in all cases when it comes to documenting factual evidence possible, therefore expert forensic one and without replaceable as evidence that argues the cause of death person.

In all cases of suspicious deaths it is needed to overlook the scene of the coroner who examined the body in general. Examination of the body at the scene will help many own coroner for giving his opinion. This examination is done in cases of death of a person suspected of the death was caused by the offense or related to the offense committed.( Azem Hajdari, E drejta e procedurës penale._Botimi 2, Prishtinë, 2010. faqe 229). If possible, the bodies should be processed for trace evidences very carefully along the autopsy just to create a clean environment in which to proceed the body and clothing, and to prevent contamination and loss of physical evidence.

According to the law Forensics, forensic autopsy is performed, but not limited to the following cases:

- doubtful murder or murder;

- $\quad$ suicide or suspected suicide;

- $\quad$ Sudden unexpected death;

- $\quad$ suspicion of torture or any other form of abuse;

- doubts during treatment;

- death during custody, detention, detention and imprisonment;

- deaths associated with police or military;

- $\quad$ unidentified bodies or skeletons, etc.( Ligji Për Mjekësinë Ligjore, Nr. 03/L-187, Neni 4, paragrafi 2) 
Processing of evidence must be done by the crime technicians who are trained in the recognition, collection, and preservation of trace evidences. Police crime technicians should assist the coroner in the collection and documentation of all physical evidence discovered in the body. This should happen in the morgue or in any other convenient location. Collection of the trace evidences should not be done at the scene. Any attempt to do so may have an effect serious in collecting adequate evidence and is likely to destroy other physical evidence that can be found at the scene.

Forensic autopsy actually is an important medical action. Through special procedures and technical-scientific, which can be performed at any stage of examination of the corpse (dissection first autopsy repeated autopsy after exhuming corpses decomposed and skeletons), autopsy aims to establish, clarify and verify forensic importance facts in the investigation of a death. ( Sokrat Meksi \&Flamur Blakaj, Mjeksia Ligjore, Prishtine, 2010, faqe 41)

The main purpose of the work of the pathologist is to determine the cause of death. Pathologist should determine links between injuries just by watching them to know the ways of death. Once the whole body and completed the examination of the autopsy, forensic pathologist will decide in determining how and cause of death.

According to the Criminal Procedure Code of the Republic of Kosovo, autopsy will be done by a qualified medical examiner by order of the State Prosecutor. The autopsy can not be trusted doctor who treated the deceased. The Ministry of Justice issued guidelines and standards related to the autopsy (Kodi i Procedures Penale te Republikes se Kosoves, Neni 139, paragrafi 1)

\section{A forensic examination of post-mortem (after death) and time of death}

The coroner who is professionally responsible to do an autopsy, and is called to give its scientific opinion on the matter. Thought should be factual and based on scientific knowledge and professional experience.

Over the course of the autopsy, if they can not find any natural cause, then there is no offense. Ex., the pathologist can conclude that the deceased had suffered a severe heart attack and as a result, the heart stopped working and the death appeared. In case of non-natural deaths, evidence not only that the lead pathologist determines the case were murder, but they help the investigation and prosecution of the case. Therefore, it is essential that the state prosecutor, the pretrial judge, a crime technician, police investigators and the coroner to work together and closely.

The main purpose of an autopsy is: identifying the body, determining cause of death and manner of death determination. A pathologist who performs autopsies should never start it without some basic information from the scene and the circumstances of death (Vincent J.M. Dimao, Managing Death Investigation, faqe. 87.)

Cooperation between the institutions mentioned above will give accurate results on the cause of death of a person. Its death will show the tool that is used to cause the death, ex: wounds from gunfire, electricity, etc. The cause of death will specifically indicate which function is disrupted body to cause death, ex: bullet passed through the heart, or the victim suffered from multiple brain injuries etc.

Immediately after the death of the man, the changes begin in the body. Some of these changes are observed entirely, while others are slimmer and become more apparent over time. It is the duty of the forensic pathologist to determine the cause of death and as far as possible the time of death.

Time is regarded as one of the most important factors in cases of murder. It's good to punish the perpetrator, break an alibi or eliminate a suspect. Evaluation of the time, especially when there are no witnesses are critical for investigation.

For a good murder investigation we need to know the time of death in order to create a basis for further investigation. Time can focus its attention to the different suspects, ex: victims may have been meeting someone at a specific time etc.

1. Immediate signs of death will be considered:

- loss of consciousness;

— sensory motor paralysis;

_ prohibition of respiratory and circulatory;

_ weakening and loss of skin elasticity; 
— signs in eyes that are very important and very diverse which form what is known as " time after death"( Sokrat Meksi \& Flamur Blakaj, Mjeksia Ligjore, Prishtine, 2010, faqe. 30,31).

2. Signs (phenomena) death early signs are beginning to appear shortly after the death of the person and last for several days. Until in the dead body see spots early, then the possibility of identification is much greater as well as the possibility of determining the type and cause of death is real. Early dead body phenomena are:

a) Cooling the body (Allor mortis) occurs as a result of termination of production of heat, because of the prohibition of metabolic processes, while eliminating it continues depending on ambient temperature where the body. Cooling the body takes place in a gradual manner, starting from the surface, mainly in the countries discovered, and generally takes the ambient temperature after 6-10 hours. In principle, body temperature pull down one (1) degree per hour and the measurements are made with the thermometer in the anus, where two minutes left. Mjekësia Ligjore, Prishtine, 2010, fq. 30,31).

(Sokrat Meksi \& Flamur Blakaj,

Cooling the body is a relative phenomenon for determining the time of death. Authorized personnel of the Department of Forensic Medicine and the Kosovo Police have available data table of the collapse of a dead body temperature, depending on the time spent and the external ambient temperature. This table is known nomogram.

The speed of the fall of temperature in the dead body, depends on factors internal and external, such as body mass and nutrition, cause of death, temperature and humidity of the environment (wind, snow, rain), clothing of the victim, place the event (air conditioning cooling or heating, etc.), ( Sokrat Meksi \&Flamur Blakaj, Mjeksia Ligjore, Prishtine, 2010, fq. 30, 31).

b) stains (marks) on the dead body (livor mortis) are created so that the interruption of circolation by natural law of force, passive blood flows into the lower parts of the body. Depending on what kind of position the body at death, hammers will be held according to the rule as follows: ex: It has been extended hammers position themselves on the back, if it was the boat they appear on the front. Death spots have colorful shades: red, blue, then brown and blue. Death spots appeared half an hour to 3 hours after death, and the maximum reach between 10 to 12 hours after death (Alija Ramljak, vep. e cit., faqe 50)

The spots vary, depending on the position of the dead body, and whether the person has stayed without moving from the time of death or if it is moved. Dead body spots, except that help to determine the time of death, they also help many to determine the position of the body at death. If the body has been moved from one place to another, this can be easily verified, ex: dead bodies would very clear spots on the back and it will be found inverted. This is a clear indication that it is moving corpse.

c) stiffness of the dead body (rigor mortis) begins to appear after his death and after the loss of muscle tone of the body, including all the muscles gradually. Initially we stiffness of the heart muscle, then squeezing still smaller muscles and finally the older ones, starting from the muscles of the face, neck, upper limb and lower limb end. So, as we noted a stiff muscle from the upper parts of the body towards the lower part of the body.

Stiffness of the dead body, primarily involving the heart muscle in the first 30 minutes, the muscles of the jaw, neck and so forth. Squeezing dead body occur between the first hour and the second death and involves all muscles after 10 hours and maintained until the beginning of the process of decay, namely 24 hours (high temperature), 48 hours (average temperature) until 72 hours (during the winter) after death, depending on external conditions and ambient temperature, humidity etc. (Fadil Batalli, Mjeksia Ligjore, Prishtine, faqe 25)

At higher temperatures, stiffness of the dead body appear faster, but it also ends quickly, unlike the premises with lower temperature, where stiffness is presented later, but lasts more time. Dead body stiffness is important not only for determining the time of death, but also is very important for determining the position of the person at death, always provided that it is not moving bodies after death.

d) drying of the corpse (dessicatio) developed under the influence of external factors, where the evaporation of moisture of the body's tissues and drying the exterior parts, where the first dry sclera, Kornet and the skin on the damaged sites (Fadil Batalli, Mjekesia Ligjore, Prishtine, ,faqe 25) 
Upon drying, the body loses 6-8 $\mathrm{kg}$ in weight, depending on the external ambient conditions. This whole process depends on the ambient conditions in which the corpse. This phenomenon occurs in those cases, when the body (corpse) is exposed to the air current (wind). Usually there are those times when the body lies in ceilings or similar premises, in cases of suicide or other criminal offenses.

3. Signs (phenomena) late or stained are signs which indicate that a corpse has died after a relatively long period of time, which can be from a few days up to several months or years. The incidence of late phenomena, depending on the distance of time, from ambient atmospheric conditions, type and manner of death, as well as other factors. Recent phenomena to the dead body are:

a) Decay (purtefactio) begins $24-48$ hours after death and decay of the body means. This process greatly depends on weather conditions, because high temperature, decay much faster place, whereas when the ambient temperature is cooler, this process takes place much more slowly. Decomposition of the body decay or occurs happen more rapidly if the ambient temperature is $25-40$ degrees, while at lower temperatures, developed more slowly decay. The decomposition of the body is faster happen in the air than in other environments, which is expressed by the formula of Casper's, indicating that the rate of decomposition of a cadaver while one (1) week in the external environment (in air) is equal to that of two (2) weeks in water and eight (8) weeks in the ground (Sokrat Meksi \& Flamur Blakaj, Mjekesia Ligjore,Prishtine, 2010, faqe 34)

The first signs of decomposition, observed after 1-2 days, where the first signs appear on the left side of the abdomen, two days later noticed on the right side of the abdomen, while the head after 4-6 days of stay of the body without buried. Decay takes place in four phases:

a) step of painting the body, where the body gets green

b) blowing stage, where due to the activity of bacteria internal and external body parts swell too greatly

c) the stage of liquefaction, where body organs receive the liquid form due to corruption and begin 36-48 hours after death

d) the stage of the carcass body starts 4-7 days after death means total liquefaction of soft organs of the body (Vincent J.M. Dimao, Managing Death Investigation, faqe 133).

b) saponification occurs in those cases where the corpse lies for a long time in any place liquids or wet, clay soil in the cemetery, with the absence of oxygen. Adipose tissue in such conditions becomes acid and glycerin soap forming layers of white to gray or yellow. These layers first appear in regions containing more fat, going from subcutaneous muscle in other parts, namely the tendency from the outside in, including muscle tissue. This process takes approximately 1-2 months to stay in the water body and sometimes even faster than 3-4 weeks. In such bodies is conserved, so that it can not penetrate the process of decay. After the restoration of the body, it has preserved its features and can be identified (Fadil Batalli, Mjekesia Ligjore,Prishtine,fq. 28). Saponification corpse can keep track on certain types of injuries, wounds, etc. strangulation furrows etc.

c) mummification a process that takes place at a time when bodies are exposed to conflicting currents of hot winds and dry ex: in the wilderness, chimneys, ceilings happens, mountains, cemetery, etc. Body in these cases shrink and compressible taking color be close to black. Skin is strengthened (compressible). Internal organs can decompose but there are cases when stored. In these circumstances the body loses much of its weight. In hot temperatures, this process takes 6-12 months, but could develop even faster (Derrick J. Pounder, Postmortem Changes and Time of Death, Department of Forensic Medicine, University of Dundee 1995. faqe 16.)

d) maceration occurs in cases where troops stay a long time in water. In this case, when these bodies taken, then their skin separates from the body and remains in the hands of the person who holds similar body as a garment to be stripped. Here skin and undress completely separated from the body (Fadil Batalli, Mjekesia Ligjore, Prishtine, faqe 25).

\title{
Bibliography
}

\author{
[1] Alija Ramljak \\ [2] Azem Hajdari, E drejta e procedurës penale. Botimi 2, Prishtinë, 2010
}


[3] Derrick J. Pounder, Postmortem Changes and Time of Death, Department of Forensic Medicine, University of Dundee 1995.

[4] Fadil Batalli, Mjekesia Ligjore, Prishtine

[5] Kodi i Procedures Penale te Republikes se Kosoves, Neni 139, paragrafi 1.

[6] Ligji Për Mjekësinë Ligjore, Nr. 03/L-187, Neni 4, paragrafi 2.

[7] Sokrat Meksi \&Flamur Blakaj, Mjekesia Ligjore, 2010, Prishtine

[8] Vincent J.M. Dimao, Managing Death Investigation 